\title{
Okul Kütüphanecilerinin Görüşlerine Göre Okul Kültürü Değerlendirmesi
}

\author{
Assessment of School Culture Based on the Views of School \\ Librarians
}

\author{
H. Inci ÖNAL* ve Selda EKiCi**
}

\begin{abstract}
Öz
Bu çalışma ile okul kütüphanelerinde görev yapan kütüphanecilerin görüşleri alınarak okul kültürünün belirlenmesi hedeflenmiştir. Araştırma örneklemini Türkiye'deki özel okul kütüphanelerinde çalışan ve Okul Kütüphanecileri Derneği'ne üye olan kütüphaneciler oluşturmaktadır. Hazırlanan anket ve ölçek, Okul Kütüphanecileri Derneği aracılığı ile üyelerine gönderilmiş, 15 farklı okuldan toplam 21 kütüphaneciden yanıt alınmıștır. Elde edilen bulgulardan, araştırma kapsamına giren okulların genel olarak "güçlü fakat geliştirilmesi gereken" kültür özelliklerine sahip olduğu tespit edilmiştir. Okul kütüphanelerinde çalışan kütüphanecilerin görüşlerine göre, okulların en güçlü olduğu kültür boyutu "etkili iletişim", en zayıf olduğu kültür boyutu ise "demokratik yönetim ve katılım" dır. "Motivasyon" boyutunda vasat ve zayıf kültür özellikleri sergileyen okulların çokluğu dikkat çekicidir, fakat olumsuzluklara rağmen "örgütsel bağlılı" boyutunda güçlü özellikler sergilendiği tespit edilmiştir.
\end{abstract}

Anahtar sözcükler: Okul kültürü, Örgüt kültürü, Okul kütüphaneleri, Okul kütüphanecileri

\begin{abstract}
The aim of this research is to determine the school culture according to the views of the librarians who work in school libraries. The sample of this research consists of librarians who work in private school libraries in Turkey and members of the Turkish Association of School Librarians. Prepared questionnaire and scale were sent to members through the Turkish Association of School Librarians and total of 21 questionnaires were obtained from 15 different schools. The results show that schools within the scope of research have "strong but developable" cultural characteristics in general. According to the views of librarians working in school libraries, schools' most powerful cultural dimension is "effective communication", the worst cultural dimension is "democratic governance and participation". There are many schools exhibiting "medium" and "low" cultural characteristics in the dimension of "motivation" but most of the schools despite negative effects exhibit "strong" cultural characteristics in the dimension of "organizational commitment".
\end{abstract}

Keywords: School culture, Organizational culture, School libraries, School librarians

* Doç. Dr., Hacettepe Üniversitesi Bilgi ve Belge Yönetimi Bölümü. (onal@hacettepe.edu.tr)

** Kütüphaneci; ODTÜ Kütüphanesi. (sekici@metu.edu.tr) 


\section{Giriş}

Bilginin sürekli arttığı ve değiştiği bilgi toplumunda, bilgiye değer veren, kullanmasını bilen, düşünebilen, aktif bireylerin yetiştirilmesi toplumun her alanında başarı açısından önemli hale gelmiştir. Okullarda, bilgi arama, değerlendirme, sentezleme, kullanma ve bilgi üretmeyi kapsayan bilgi okuryazarlığının geliştirilmesi ve uygulanmasında öğretmenlerin ve okul kütüphanecilerinin işbirliği yapması daha anlamlı bir öğrenim süreci yaşanmasını sağlar. Ayrıca öğrenciler, kendileri için anlamlı bilgileri araştırabildiklerinde daha hızlı öğrenmekle kalmaz, okuryazarlık becerilerini de hızla geliştirir, öğrenmeyi öğrenirler (Celep, 2002; Scholastic Library Publishing, 2008). Okullarda kütüphanelerin kurulabilmesi ve hizmet verebilmesi için, uygun zemin ve olanaklar olmalıdır. Bu da gelişmiş bir okul kültürü ile sağlanabilmektedir. Özellikle idarecilerin ve öğretmenlerin okul kütüphanelerinin eğitime olan hayati katkısının farkında olmalarını gerektirmektedir. Bu çalışma ile okul kütüphanelerinde görev yapan kütüphanecilerin görüşleri doğrultusunda okul kültürünün saptanması hedeflenmiştir.

\section{Örgüt Kültürü}

Örgüt kültürü, örgütteki bireylerin davranışlarını yönlendiren normlar, değerler, inançlar ve alışkanlıklar sistemidir (Dinçer, 1992). Başka bir deyişle örgüt kültürü, çalışan kişilerin örgütle bütünleşmesini sağlayan değerler ve inançlardır.

Örgüt kültürünün oluşturulmasında lidere önemli görevler düşmektedir. Lider örgütte çalışanlar tarafından benimsenebilecek, onlara yol gösterecek, kalıcı ve geçerliliğini kolayca yitirmeyecek somut değerler sistemi oluşturmalıdır. Çalışanlara rol modeli hazırlamakla kalmayıp; onları motive edebilecek kahramanlar yaratmalıdır. İş görenler arasındaki takım ruhu, birlik, ait olma duygularını ortaya çıkararakyakınlaşmaları sağlaması; törenler düzenlemesi ve örgüt kahramanlarına ilişkin efsaneler oluşturması yoluyla temel değerlerin gelecek nesillere aktarılması kurum liderinin örgüt kültürü oluşturma sürecindeki sorumlulukları kapsamındadır (Alganer, 2000).

Örgüt kültürünün yeni gelenlere aktarılması ve insan kaynakları uygulamaları, kültürün hem geliştirilmesi hem de pekiştirilmesi açısından büyük önem taşımaktadır. Çalışanların seçilmesi, iş tanımlarına uygun görevlere yerleştirilmesi, performanslarının belli ölçütlere göre değerlendirilmesi, ödüllendirme uygulaması, sürekli eğitim ve mesleki geliştirme etkinlikleri, terfi işlemleri örgüt kültürüne uyum ve gelişim açısından önemlidir (Güçlü, 2003, s.149). Çalışanların çoğunluğu tarafından paylaşılan temel değerler örgütteki baskın kültürü, örgüt çalışanları arasında sadece belli bir grup tarafından paylaşılan değerler ise alt kültürü temsil etmektedir. Örgütler tarafından özümsenmiş amaçlar, gerçekleştirilen işbirlikleri ve paylaşılmış değerler güçlü kültürlerin oluşmasını sağlamaktadır. Zayıf kültürlerin olduğu örgütlerde ise çalışanlar arasındaki bağ gevşektir. Güçlü örgüt kültürlerinde tüm çalışanların kültürel değerleri, öğretme, öğrenme, kolaylaştırma, paylaşma gibi süreçleri içselleştirmeleri, çalışanlarda 
motivasyon, bağlılık ve performans artışı sağlamakla birlikte örgütten ayrılma oranlarını azaltmaktadır (Erdem ve Özen-İşbaşı, 2001). Bu da örgütün başarısının artışında önemli bir etkendir.

\section{Okul Kültürü}

Okul kültürü kavramı örgüt kültürü ile ilgili bir faktör olarak kullanılmıştır. Okul kültürü bir okulda örgütsel bütünleşmeyi sağlayan; çalışanın işlemlerini nitelendirmeye, değerlendirmeye ve yargılamaya yarayan; kültür içinde davranışı etkileyen, sosyal sistemi kurumsallaştıran ve güçlendiren, değer, norm, inanç, gelenek, tören, hikâye ve kültürel semboller gibi çeşitli ölçütlerin tümüdür.

Okul kültürünü belirleyen faktörler şu şekilde sıralanabilir (Brown, 2005, s.3-7, 24-51; Özdemir, 2006, s.414):

$\diamond$ Okulun yaşı,

$\diamond$ Okulun tarihî gelişim süreci,

$\diamond$ Okulun amacı ve hedefleri,

$\diamond$ Okulun bulunduğu sosyoekonomik ve coğrafi çevre,

$\diamond$ Öğrencilerin sosyoekonomik düzeyleri,

$\diamond$ Kırsal ve kentsel alanlar,

$\diamond$ Okulun tesisleri,

$\diamond$ Okulda kullanılan teknoloji,

$\diamond \quad$ Okul ve sınıf büyüklüğü,

$\diamond$ Yönetici, öğretmen ve öğrencilerin beklentileri,

$\diamond$ Velilerin beklentileri,

$\diamond$ Eğitim sisteminin merkeziyetçi olup olmaması,

$\diamond$ Eğitim kurumlarının özel olup olmaması,

$\diamond$ Eğitim sisteminin yapısı.

Bir okulun etkinliğinin göstergesi sahip olunan kültürdür. Okul geliştirmenin amacına ulaşmasında en etkin adım, değişime ilişkin olumlu tutum geliştirilmesini sağlayan pozitif okul kültürünü yapılandırma olacaktır (Şahin, 2010, s.562). Olumlu pozitif kültür örgüt üyeleri arasında düşünce birliği oluşturur, her türlü başarıyı etkiler, düşüncelerin net, açık ve birbiriyle uyumlu olmasını sağlar. Güçlü bir okul kültürü yönetici, öğretmen ve çalışan diğer personelin ortak norm, değer ve inançlar etrafında birleşmesiyle oluşur. Yöneticiler, örgütsel deneyim ve içsel etkileşim okul kültürünün oluşturulmasında anahtar öğelerdir. Okul yöneticileri yasal ve kişisel bir güce sahip olmalarından dolayı okulun yapısını biçimlendirmekle kalmazlar. Aynı zamanda yöneticilerin değer, tutum, inanç ve görüşleri çalışanlar tarafından kabul edildiğinde ve 
devam ettirildiğinde okul kültürünün bileşenleri arasında yer almaya başlarlar (Şimşek, 2003, s.9; Berg, 2005). Özellikle yeni bir okula yönetici konumunda gelen yöneticilerin, oluşturulan güçlü kültürün korunması ve geliştirilmesi konularında dikkatli davranarak güçlü kültür özelliklerini bozmaması gerekir. Çünkü iyi yönetilen okullar, güçlü okul kültürü özelliklerine sahip olabilmektedirler.

Okullar için örgütsel deneyim ve kendi okul kültürlerini oluşturmak önemli olup, her okul toplumda kendisine olumlu bir yer bulmaya çalışmakta ve yöneticinin liderliğinde olumlu uygulamaları hayata geçirmek üzere çaba sarf etmektedirler. Okul kültürünün oluşmasında anahtar öğelerden biri kurum içi etkileşimdir. Kurum içi etkileşimin oluşmasında yöneticiye önemli görevler düşmektedir. Etkileşimde bulunan üyeler okulun çalışmasıyla ilgili süreçleri benzer algılamakta ve birlikte çalışma deneyimleri oluşturmaktadırlar (Şimşek, 2003, s.12). Güçlü kültüre sahip okullarda öğrenme ve öğretim işbirlikçidir; okula karşı olumlu bağlılık geliştirilmesi hedeflenir; öğrencilere yakınlık; mükemmellik için uğraşma; çalışmaya istekli olma; iletişimde açıklık; iyi geçinme ve profesyonel olma gibi ögeler okulda yapılandırılmıştır (Balcı, 1993; Atay, 2001). Bir okulda başarı için, her şeyden önce, akademik başarıya değer veren, başarılı uygulamalar yapan, etkili öğrenimi teşvik eden bir düzenle birlikte disiplin öngören ve işbirlikçi ilişkileri ön planda tutan bir kültürün oluşturulması gerekir (Demirtaş, 2010, s.5).

\section{Güçlü ve Zayıf Okul Kültürü Özellikleri}

Etkili okul kültürlerinin özellikleri şu şekilde sıralanabilir (Pehlivanoğlu, 1999, s.31-36; Fırat, 2007, s.53):

$\diamond \quad$ Etkili okulların öğretimsel uygulamalara ilişkin paylaşılmış deneyimleri vardır.

$\diamond$ Bir lider olarak yöneticiye karşı inanç bulunmaktadır.

$\diamond \quad$ Öğretme ve öğrenmeye ilişkin güçlü inançlar beslenir.

$\diamond \quad$ Öğretmenler rol modelleri olurken, öğrenciler ise gerçekleştirmek istedikleri rol modeline uygun sorumluluk taşıma pozisyonundadırlar.

$\diamond \quad$ Önemli törenler, gelenekler ve ritüeller bulunmaktadır.

$\diamond \quad$ Katı olmayan düzenli bir atmosfer vardır. Sorumluluk, baskıyı gerektirmemektedir.

$\diamond \quad$ Öğretmenler ve çalışanlar karara katılırlar.

Bünyelerinde zayıf kültürü barındıran okullarda ise (Özdemir, 2006, s.416).

$\diamond \quad$ Yönetici, öğretmen, öğrenci ve veli arasındaki bağlar zayıflamıştır.

$\diamond$ Tüm üyeler birbirlerine karşı düşük başarı beklentisi içindedirler.

$\diamond$ Diyalog zayıflamıştır.

$\diamond$ Motivasyon düşüktür.

$\diamond \quad$ Üyeler arasında kuşku ve düşmanlık hisleri yaygındır. 
$\diamond$ Yıkıcı çatışmalar artmıştır.

$\diamond$ Koordinasyon bozulmuştur.

$\diamond$ Üyeler arasında sevgi-saygı zayıflamıştır.

\section{Okul Kültürü İçinde Okul Kütüphanesinin Önemi}

Okul kültürü içinde okul kütüphanesinin önemini aşağıdaki başlıklar altında görebiliriz (Önal, 1999; 2005; Scholastic Library Publishing, 2008):

$\diamond \quad$ Okul kütüphaneleri eğitimin amaçlarını gerçekleştirmede ve öğrencilerin başarısını sağlamada hayati derecede önemlidir.

$\checkmark$ Kütüphaneciler ve/veya medya uzmanları, sınıftaki imkânları değiştirmek için öğretmenlerle işbirliği yapmakta ve öğrenim fırsatlarını kitaplar, elektronik kaynaklar ve diğer unsurlarla desteklemektedirler. Bu yönüyle okul kütüphanelerinin öğretimdeki rolü büyüktür.

$\checkmark$ Artık okul kütüphaneleri sadece kitap arşivi değil, bilgisayar kaynaklarını da içeren medya merkezleri şeklindedir. Eğitimli personele sahip bu merkezler, elektronik bilgilerin sadece merkezde kullanılmasını değil, sınıflara taşınması ve müfredata uygulanmasını sağlayarak öğretime destek verirler.

$\diamond$ Öğrenciler çeşitli okur yazarlık becerileri ve okuma alışkanlığı kazanmaya özendirilirler.

$\diamond$ Mesleki eğitim görmüş, üstün nitelikli kütüphaneciler olmadan okul kütüphanelerinden başarı beklemek mümkün değildir.

$\diamond$ Etkili okul kütüphaneleri fikirlerin araştırılacağı ve tartışılacağı buluşma noktaları olmalıdır.

Okul kütüphanelerinin yukarıda istenen hedeflere ulaşmasında bulunduğu okulun kültürü önemlidir. Üst düzey kültür özellikleri sergileyen bir okul olabilmek için okul kültürünün boyutları arasında kütüphanenin varlığı saptanmalıdır.

\section{Okul Kültürünün Boyutları ve Kütüphane}

Okul kültürünün çeşitli boyutları vardır. Bu araştırma kapsamında okul kütüphanelerinin kurulmasını ve başarısını etkileyen okul kültürünün boyutları “Örgütsel bağlılık”, “Etkili Illetişim”, "İ̧̧birliği ve Güven”, “Destek”, “Motivasyon ve Verimlilik”, «Demokratik Yönetim ve Katılım», başlıkları çerçevesinde incelenmiştir.

\section{Örgütsel Bağlılık}

Örgütsel bağlılık okul personelinin davranışlarını yönlendiren belirli standartları, normları, değerleri, inançları ve alışkanlıkları anlayarak kendilerinden beklenen başarıya ulaşmaları konusunda daha kararlı ve tutarlı olmalarını sağlamaktadır. Ayrıca, personelin kuruma daha uyumlu, özverili, bütünleşik ve aidiyet duygularıyla çalışarak verimliliğin 
artmasına yardımcı olmaktadır (Atay, 2001, s.181). Okul yöneticilerinin sayılan bu konularda okul personelinin aidiyet duygularını geliştirmek için özel çaba harcamaları son derece önemlidir. Güçlü okul kültürlerinde örgütsel bağlılığı sağlamlaştıran uyumlu ve adil olma, etkileşime önem verme, kişisel çabaya saygı duyma büyük önem kazanmaktadır. Okulda "ben" bilincinden çok "biz" bilincinin olması, kişilerin birbirinin başarısından ve okulun başarısından mutluluk duyması örgütsel bağlılığın önemli noktalarındandır. Okul kütüphanecilerinin örgütsel bağlılık ve aidiyet duygularının geliştirilmesi için okul yöneticilerinin harcayacağı özel çaba güçlü okul kütüphanelerinin oluşmasında etkili olacaktır. İyi bir okul kütüphanesinin varlığı ise eğitime ve başarıya önemli katkı sağlayacaktır.

\section{Etkili IIletişim}

Etkili iletişim çift yönlü iletişimdir. Güçlü kültürlere sahip okullarda müdür-öğretmenöğrenci-aile-kütüphaneci-personel-çevre arasında iletişim süreçleri söz konusudur. Farklı boyutlarda olabilecek bu süreçlerde önemli olan nokta etkili, açık ve çift yönlü olmaktır. Daima başarı, motivasyon ve verimliliğin artması beklenmektedir.

Her ne kadar okulun asıl işi olan öğretim, sınıfta öğretmenin kılavuzluğu, yönlendirmesi ve denetiminde, öğrenci-öğretmen etkileşimiyle gerçekleşse de (Balcı, 1993), çocuğun okulda geçirdiği zaman, ailesi ve çevresiyle geçirdiği zamana göre daha kısa olduğundan, okul öğrenmelerinin aile çevresinde de desteklenmesi gereklidir (Fırat, 2007, s.57). Bu bağlamda okul-aile işbirliğinin sağlam temeller üzerine oturtularak öğrencilerin başarılı olmaları için kütüphanenin önemli bir araç olarak kullanılması çok önemlidir.

\section{İşbirliği ve Güven}

Eğitimsel amaçlar doğrultusunda okuldaki bireylerin oluşturdukları çalışma ortaklığıyla kurulan işbirliği (Fırat, 2007, s.55), kütüphanecilerin katkısıyla başarının, verimliliğin, kalitenin ve mesleki gelişimin temelinde yer alacaktır. Bilgi okuryazarlığı becerilerini kazandırmak, öğretim programlarına destek olmak, teknoloji yardımı ile öğrenimi zenginleştirmek, okuma alışkanlığı kazandırmak, koleksiyon geliştirmek başta olmak üzere çeşitli konularda kütüphanecilerle özellikle öğretmenler arasında, daha sonra da, okul yönetimi, idareciler, veliler, çeşitli kurumlardan kütüphaneciler, konu uzmanları ve ilgili kişiler arasında düzenli işbirliği olmalıdır. İşbirliğinin yönetim tarafından desteklenmesi son derece önemlidir. Ayrıca özellikle okul yönetimine duyulan güven, işbirliğini olumlu yönde etkilemektedir. Bunun tersi olarak işbirliğini zedeleyici davranışlar, okul yönetiminin velileri parasal kaynak olarak görmeleri ve bütçenin hizmetlere yeterince yansımaması okul çapında güven kaybı oluşturmakla kalmayıp, okul kültürünün zayıflamasına da neden olmaktadır.

\section{Destek}

Okullarda düşünce özgürlüğünün yaşanması, eğitim ve öğretimde yeniliklerin izlenerek uygun görüldüğünde desteklenmesi, öğrenme zevkinin aşılanması, okul ve çevre 
işbirliğinin kurulmasına dair çaba harcanması ve sürekli gelişim için yenilikleri yönetim tarafından desteklenmesi güçlü okul kültürü yaratılmasında önemlidir. Kütüphanelerin teknolojik gelişmelere uyum sağlaması için girişimlerde bulunulması ve etkin hizmet verilebilmesi için yeterli bir bütçe ile desteklenmesi gerekmektedir.

\section{Motivasyon ve Verimlilik}

Okulda uygun eğitim, öğretim ve çalışma ortamları yaratarak, bu kapsamda bireyleri istekle çalışmaya yöneltecek etkilenme sürecinin başlatılması motivasyonla gerçekleşmektedir (Şimşek, 2003, s.26). Çalışanların motivasyonunun artırılmasında en büyük görev, ilgili okulun yöneticilerine düşmektedir. Yöneticilerin her bir bireyin fikirlerine ve kişiliklerine saygı göstermesi, çalışmaların desteklemesi ve çeşitli faaliyetlere katıımını sağlaması, çalışanın motivasyonunu yükseltecek ve verimliliğini artıracaktır.

$\mathrm{Bu}$ ortamda okul kütüphanecilerinin de mesleki anlamda gelişimlerinin desteklenmesi, yükselme olanaklarının sağlanması, maddi anlamda doyuma ulaştııımaları; onların yüksek motivasyonla çalışmalarını olumlu yönde etkileyecek ve hizmetlerde verimlilik artışı sağlanacaktır. İ̧ini severek ve isteyerek yapan personelin verimliliği okul kültürünün artmasını etkileyecektir.

\section{Demokratik Yönetim ve Katılım}

Fırat (2007)' a göre demokratik okul yönetimi denildiğinde personele, öğrencilere ve velilere yönelik hakların gözetimi akla gelmektedir. Böylece okulun birçok biriminde görev alacak temsilcilerin seçim yoluyla belirlenmesi (örneğin öğrenci temsilciliği), yönetime katılma hakkının işletilmesi ve şeffaf yönetim anlayışı gerçekleşecektir. Belirtilen şeffaf yönetim anlayışı çerçevesinde özgür çalışma ortamları sağlanacak, personelin ve öğrencilerin kendilerini özgürce ifade edebilmelerine olanak tanınacaktır. Ayrıca bu yönetim anlayışı çerçevesinde başarılı uygulamaların gerçekleşeceği, eşitliğin ortak bir değer olarak benimseneceği, farklılıkların birer olumluluk olarak algılanacağı vb. akla gelmektedir.

Kütüphanecilerin, görevlerini özgür bir ortamda yapabilmeleri, düşünce ve görüşlerini açıkça ifade edebilmeleri ve görevleriyle ilgili belirsizliklerde kendi başlarına karar verebilmeleri yönetime katılmalarının açık göstergeleridir. Yönetim tarafından herkese eşit davranma temel bir değer olarak benimsenmeli ve ödül dağıtımında adil olunmalıdır. Okul yönetimi ile kütüphanecilerin düzenli toplantılar yapmaları ve ortak kararlar vermeleri öğrenimin iyileştirilmesi açısından büyük önem taşımaktadır.

\section{Önceki Çalışmalar}

II. Dünya Savaşı'nın ardından Amerika Birleşik Devletleri'nin yönetim ve işletmecilik alanındaki üstünlüğü kabul edilirken, 1970'lerden itibaren Japon işletmelerinin yeni başarılar kazanarak Amerikan işletmelerinin önüne geçmeleri, araştırmacıları bunun nedenini aramaya yöneltmiştir. Örgüt kültürü ile ilgili kavramların ortaya çıkması ve 
uygulanması gelişmelerin başlangıç nedenleri arasındadır. Ayrıca örgütte çalışanların dahil oldukları çeşitli alt kültürlerin bulunması ve bunlar arasında çatışmalar yaşanması, o örgüte ait, tek ve onları temsil eden üst kültür geliştirmelerine neden olmuştur. Genel olarak örgüt kültürü konusundaki çalışmaların 1970'lerde başladığı, 1980'lerde önem kazanarak bütün dünyaya yayıldığı anlaşılmaktadır.

Örgüt kültürünün genel özelliklerini tanımlayan (Güçlü, 2003) çalışmalar zamanla çeşitlenmiştir. Bu konuyla ilgili olarak Türkiye'de üzerinde çok çalışılan konulardan biri okul kültürü olmuştur. Örnek olarak şu çalışmalar verilebilir:

$\diamond \quad$ Illköğretim kurumlarında öğretmen, yönetici ve deneticilerin bakış açısından okul kültürünün öğretmenlerin verimliliğine etkisi incelenmiştir. Ayrıca, yöneticilerinin kültürel liderlik davranışları değerlendirilmiş ve öğretmen verimliliğine olan etkileri araştırılmıştır. Araştırma sonucunda, ilköğretim okullarının güçlü örgütsel kültüre sahip olmadığı ve yöneticilerin kültürel liderlikteki başarısızlıkları tespit edilmiştir (Atay, 2001).

$\diamond$ Üniversite son sınıf öğrencilerinin örgüt kültürüne yönelik algıları ile ilgili yapılan çalışmada, öğrencilerin aidiyet duyguları, semboller ve öğretim üyeleri ile olan iletişimleri incelenmiştir. Araştırma sonucunda, öğrencilerin örgütsel yapı-işleyiş boyutunda olumsuz algılamalara sahip oldukları, eğitim sürecinin etkililiği ve sonuçları konusunda ise ortak algılamaların oluşmadığı görülmüştür (Erdem ve Özen-İşbaşı, 2001).

$\diamond \quad$ Okul müdürlerinin iletişim becerileri ile okul kültürü arasındaki ilişkinin incelendiği araştırmada, 706 öğretmene anket uygulanmış ve öğretmen görüşlerine göre okul müdürlerinin iletişim becerileri ile okul kültürü arasında anlamlı bir ilişki olup olmadığı belirlenmeye çalışılmıştır. Araştırma sonucunda okul müdürlerinin iletişim becerileri ile okul kültürü arasında yüksek düzeyde başarılı ve olumlu ilişkiler olduğu tespit edilmiştir (Şimşek, 2003).

$\diamond \quad$ Okul kültürünün oluşturulmasında okul müdürlerinden beklenen davranışlarla ilgili yapılan araştırmada 251 Bakanlık müfettişine anket uygulanmış ve okul müdürlerinden beklenen davranışlar ile gözlemlenen davranışlar karşılaştırılmıştır. Araştırma sonucunda, müfettişlerin, okul kültürünün oluşturulması ve çevreye tanıtılmasıyla ilgili olarak okul müdürlerinden bekledikleri davranışların, onlarda gözledikleri davranışlardan daha yüksek düzeyde olduğu belirlenmiştir (Özdemir, 2006).

$\diamond \quad$ Illköğretim okullarındaki kültürlerin öğrenci başarısı üzerindeki etkilerini inceleyen bir araştırmada, 784 öğretmene okul kültürü ölçeği uygulanmıştır. Elazığ ili sınırlarında 2007-2008 öğretim yılında uygulanan seviye tespit sınavında 8.sınıflardan elde edilen sonuçlar öğrenci başarısını gösteren bir ölçüm olarak alınmıştır. Bu araştırma sonucunda, öğrenci başarısı ile okul kültürünün işbirlikçi liderlik, öğretmen işbirliği ve amaç birliği faktörleri arasında anlamlı bir ilişki olduğu tespit edilmiştir (Demirtaş, 2010). 
Doğrudan doğruya okul kültürünün boyutları ve kütüphane arasındaki bağlantının ortaya çıkartılmasında Howard (2008) tarafından gerçekleştirilen çalışma örnek olmuştur. Belirtilen bu çalışma okul kültürü ile kütüphane programları arasındaki ilişkiyi araştırmış, araştırma kapsamında bulunan okullardaki kültürel temaları tespit etmiştir. Çalışma kapsamında, etkili okul kütüphanesi programlarına sahip olarak ulusal ödül almış dört okulda vaka çalışması yapılmış ve okul kültüründe kütüphane programının özellikleri tespit edilmeye çalışılmıştır. Veri toplamak için örgüt kültürü ve etkili okul kütüphanesi programları ile ilgili kaynak taraması yapılmış, gözlem, görüşme ve anket uygulanmıştır. Araştırma sonucunda okul kültürü, liderlik ve etkili okul kütüphanesinin programları arasında olumlu ilişkiler bulunduğu tespit edilmiştir.

Türkiye'de okul kültürü ve kütüphane arasındaki etkileşimi inceleyen araştırmalara henüz rastlanmamıştır.

\section{Araştırmanın Amacı, Kapsamı ve Yöntemi}

Güçlü bir okul kültürünün yapılandırılması öğrenme becerilerini desteklemekle kalmaz öğretmen, öğrenci, kütüphaneci ve diğer okul personeli için yüksek motivasyona dayalı başarı sağlamaktadır. Bu çalışmanın amacı; kütüphanecilerin bakış açısıyla okul kültürünü belirlemek, okul organizasyon yapısı içinde kütüphane ve kütüphanecilerin yerini tespit etmek ve okul kütüphanecilerinde okul kültürünün etkilerini değerlendirmektir. Belirtilen amaç bağlamında çalışmanın hipotezi "Okul kültürü boyutları içinde yer alan örgütsel bağlılık, etkili iletişim, işbirliği ve güven, destek, motivasyon ve verimlilik, demokratik yönetim ve katılım konularında okul kütüphanelerinde görev yapan kütüphanecilerin yeterince destek görmemesi nedeni ile, okul kütüphanecileri okul kültürü hakkında üst düzeyde olumlu düşüncelere sahip değillerdir" biçiminde oluşturulmuştur.

Araştırmanın amacını gerçekleştirebilmek için aşağıda belirtilen yol izlenmiştir: Araştırmada okul kültürü ve kütüphane konularıyla ilgili yayın taraması yapılmıştır. Okul kütüphanecilerinin okul kültürüne ilişkin görüşlerini ölçmek amacıyla tarafımızdan geliştirilen «Okul Kültürü Ölçeği» kullanılmıştır. Daha sonraki aşamada ise elde edilen bulgular yorumlanarak öneriler geliştirilmiştir. Araştırmada betimleme yöntemi uygulanmıştır.

Araştırmanın evrenini, Türkiye'deki özel okul kütüphanelerinde çalışan ve Okul Kütüphanecileri Derneğine üye olan kütüphaneciler oluşturmaktadır. Okul Kütüphanecileri Derneğinin 2011 yılı sonu itibariyle üye sayısı 32 okuldan 44 kütüphanecidir. Hazırlanan anket ve ölçek, Okul Kütüphanecileri Derneği aracılığı ile üyelere gönderilmiş, 15 farklı okuldan toplam 21 kütüphaneciden yanıt alınmıştır. Araştırmamıza katılan 15 okulun adları Ek: 1'de verilmiştir. Okul Kütüphanecileri Derneği'ne üye 32 okuldan $\% 46,9^{\prime} u$, üye kütüphanecilerden $\% 47,7^{\prime}$ si araştırma kapsamındadır. Verilerin çözümlenmesinde SPSS 17.0 kullanılmış ve aritmetik ortalama, yüzdelik dağılım ve faktör analizi uygulanmıştır. 
Anketin birinci bölümünde, kütüphanecilere ait cinsiyet, yaş, öğrenim düzeyi, okuldaki görev süreleri, kadrolarına yönelik kişisel verilerle birlikte okulun kuruluş yılı, öğrenci, öğretmen, personel ve kütüphaneci sayıları gibi bilgileri toplamak amacıyla hazırlanan sorular yer almaktadır.

Anketin ikinci bölümünde, 3 olumsuz 32 olumlu cümleden oluşan ve kütüphanecilerin okul kültürüne ilişkin görüşlerini ölçmeye yönelik bir ölçek bulunmaktadır. Tepki kategorileri "tümüyle katılıyorum, katılıyorum, karasızım, katılmıyorum, hiç katılmıyorum" olarak belirlenmiştir. Uygulamadan elde edilen cevapların puanlanması olumlu cümlelerde tümüyle katılıyorum' dan başlayarak "5-43-2-1"; olumsuz cümlelerde ise "1-2-3-4-5" şeklinde yapılmıştır. Araştırmamızın anketi Ek 2'de verilmiştir.

Kütüphaneci görüşlerine göre okul kültürünü belirleyebilmek için, kütüphanecilerden elde edilen verilerin değerlendirilmesi okullar bazında yapılmıştır. Okul bazında kültürün değerlendirilebilmesi için, bir okulda görev yapan kütüphanecilerin, anketin ikinci bölümünde yer alan 35 soruya verdiği cevapların önce her kütüphaneci için aritmetik ortalamaları belirlenmiştir. Bunun ardından, o okulda görev yapan kütüphanecilerin aritmetik ortalamaları toplanarak bunların bir ortalaması alınmıştır. Bulunan bu aritmetik ortalama 4,20-5,00 arasında yer almışsa, okul kültürü "üst düzeyde güçlü"; 3,40-4,19 arasında yer almışsa "güçlü fakat geliştirilmesi gereken"; 2,60-3,39 arasında yer almışsa "vasat"; 2.59-1,00 arasında yer almışsa "zayıf" olarak değerlendirilmiş ve yorumlanması bu yönde yapılmıştır.

Kütüphanecilerin okul kültürüne yönelik görüşlerini değerlendirmek amacıyla okul kültürünün boyutları altıya ayrılmış ve bunlar, ilgili sorular aracılığı ile ölçülmüştür. Okul kültürü boyutları Tablo l'de verilmiştir.

Tablo I. Okul Kültürü Boyutları ve İlgili Sorular

\begin{tabular}{lll}
\hline Boyut & Okul Kültürü & Boyutlarla ilgili Sorular* \\
\hline 1 & Örgütsel bağlııı & $3,11,15$ \\
2 & Etkili iletişim & $6,17,35$ \\
3 & İşbirliği ve güven & $5,9,13,14,22,23,24,25,26,28$, \\
4 & Destek & $18,19,20,31,32$ \\
5 & Motivasyon ve verimlilik & $4,10,21,29,30$ \\
6 & Demokratik yönetim ve katılım & $1,2,7,8,12,16,27,33,34$ \\
\hline
\end{tabular}

* EK 2' de verilen anketin ikinci bölümünde yer alan sorular aracılığı ile okul kültürü boyutları ölçülmüştür. 


\section{Bulgular ve Yorum}

Bu bölümde, araştırma kapsamındaki okulların sahip oldukları kültür boyutları, okullar bağlamında, araştırmaya katılan kütüphaneci gurubundan elde edilen veriler doğrultusunda belirlenmiştir.

Özel okullarda görev yapan kütüphanecilere ait kişisel bilgilerin çözümlenmesinde frekans ve yüzdeler kullanılmıştır. Kütüphanecilerin çoğunluğunu bayanlar $(\% 80,95)$ ve 31-41 yaş $(\% 47,6)$ aralığı oluşturmaktadır. Araştırma kapsamında bulunan kütüphanecilerin cinsiyet ve yaş bilgileri Tablo II'de verilmiştir.

Tablo II. Araştırmaya Katılan Kütüphanecilere Ait Kişisel Bilgiler

\begin{tabular}{lccccc}
\hline Cinsiyet & Sıklık & $\mathbf{\%}$ & Yaş & Sıklık & $\%$ \\
\hline Erkek & 4 & 19,05 & 30 yaş altı & 4 & 19,1 \\
Kadın & 17 & 80,95 & $31-41$ & 10 & 47,6 \\
& & & 41 ve üzeri & 7 & 33,3 \\
Toplam & $\mathbf{2 1}$ & $\mathbf{1 0 0 , 0}$ & Toplam & $\mathbf{2 1}$ & $\mathbf{1 0 0 , 0}$ \\
\hline
\end{tabular}

Tablo Ill'te görüldüğü üzere araştırmaya katılan kütüphanecilerin çoğunluğu (\%95,2), Kütüphanecilik / Bilgi ve Belge Yönetimi Bölümü (4 yıllık lisans programı) eğitimi almış, alanında uzman kişilerden oluşmaktadır. Kütüphanecilerden biri Kütüphanecilik lisans eğitiminden sonra Eğitim Yönetimi alanında yüksek lisans ve doktora eğitimini de tamamlamıştır. Bu da son yıllarda önem kazanan ve özellikle okul kütüphanelerinde bulunması gereken "öğretmen kütüphaneci" kavramına güzel bir örnektir. Öğretmenkütüphanecilerin olduğu okul kütüphanelerinde bilgi okuryazarlığı, medya okuryazarlığı gibi becerilerin öğrencilere kazandırılmasında, diğer öğretmenlerle işbirliği yapılması ve müfredata bu becerilerle ilgili derslerin eklenmesi mümkün olabilmektedir. Güçlü okul kültürü oluşturulmasında işbirliğinin önemi göz önünde bulundurulursa, okullarda nitelikli ve kütüphanecilik eğitimi almış kütüphanecilerin istihdam edilmesi nitelikli işbirliği açısından önemlidir.

Tablo III. Araştırmaya Katılan Kütüphanecilerin Öğrenim Düzeyleri

\begin{tabular}{lcccc}
\hline \multicolumn{4}{c}{ Mezun Olunan Bölüm } \\
\hline & $\begin{array}{c}\text { Kütüphanecilik / } \\
\text { Bilgi ve Belge Yönetimi }\end{array}$ & $\begin{array}{c}\text { Dış } \\
\text { Ticaret }\end{array}$ & $\begin{array}{c}\text { Eğitim } \\
\text { Yönetimi }\end{array}$ & Toplam \\
\hline 2 yıllık ön lisans programı & 16 & 1 & & $\mathbf{1}$ \\
4 yıllık lisans programı & 2 & & & $\mathbf{1 6}$ \\
Yüksek Lisans Programı & 1 & & 1 & $\mathbf{2}$ \\
Doktora Programı & $\mathbf{1 9}$ & $\mathbf{1}$ & $\mathbf{1}$ & $\mathbf{2 1}$ \\
Toplam & & & & \\
\hline
\end{tabular}


Tablo IV'e göre araştırmaya katılan kütüphanecilerden sadece 3'ü görevde yükselmiş, diğerleri bulundukları aynı kadroyla görevlerini sürdürmektedirler. Bu verilere göre okullarda kütüphanecilerin yükselme olanaklarının bulunmadığı söylenebilir.

Tablo IV. Araştırmaya Katılan Kütüphanecilerin Kadrosu

\begin{tabular}{lcc}
\hline & \multicolumn{2}{c}{ Bulunulan Aynı Kadro ile Başlayanlar ve Yükselenler } \\
\hline & Aynı Kadroda Çalışanlar & Yükselenler \\
\hline Memur & 5 & \\
Kütüphaneci & 6 & 1 \\
Şef / Birim Sorumlusu & 4 & 2 \\
Müdür & 3 & \\
Toplam & $\mathbf{1 8}$ & $\mathbf{3}$ \\
\hline
\end{tabular}

Araştırmamızda yer alan kütüphanecilerin çoğu kütüphaneci kadrosunda bulunmaktadır. Bir kısmı ise memur kadrosunda çalışmaktadır. Verilere göre statü sorunu görünmemektedir ancak doğru değerlendirmeler için kütüphanecilerin okullarında algılanış biçimlerine bakmak gerekmektedir. Güçlü okul kültüründe motivasyon önemli bir boyuttur. Kütüphanecilerin iş motivasyonunun yüksek olması ve verimli çalışmaları da önemlidir. Kütüphanecilerin görevde yükselme olanağının bulunması da motivasyonu yükseltecek konulardan biridir.

\section{Araştırmaya Katılan Okullar ile İlgili Bulgular}

Araştırmaya katılan okullardan Okul 9 ve Okul 5, 1863 ve 1871 yıllarında kurulmuş, köklü okullardır. Okul 6 ve Okul 7'de 1931 ve 1943 yıllarında kurulmuş ve 70 yılı aşkın süredir eğitim hayatında yer almaktadır. Özellikle Okul 6’nın öğrenci sayısı göz önüne alındığında tercih edilen bir okul olduğu söylenebilir. Okulların öğrenci sayısı ile hizmet veren kütüphaneci sayıları kıyaslandığında Okul 12'nin en fazla kütüphaneciye sahip olması dolayısıyla okulun kütüphanecileri önemsediği sonucuna varılabilir fakat Okul 12 'den sadece bir kütüphanecinin görüşü alınabildiği için genelleme yapılamamaktadır. Araştırmaya katılan okullarla ilgili bilgiler Tablo V'de verilmektedir. 
Tablo V. Araştırmaya Katılan Okullar İle İlgili Bulgular

\begin{tabular}{lcccccc}
\hline Okul & $\begin{array}{c}\text { Kuruluş } \\
\text { Tarihi }\end{array}$ & $\begin{array}{c}\text { Ögrenci } \\
\text { Sayısı }\end{array}$ & $\begin{array}{c}\text { Öğretmen } \\
\text { Sayısı }\end{array}$ & $\begin{array}{c}\text { Personel } \\
\text { Sayısı }\end{array}$ & $\begin{array}{c}\text { Kütüphaneci } \\
\text { /Yardımcı } \\
\text { Personel Sayısı }\end{array}$ & $\begin{array}{c}\text { Araştırmaya } \\
\text { Katılan } \\
\text { Kütüphaneci } \\
\text { Sayısı }\end{array}$ \\
\hline Okul 1 & 1986 & 830 & 80 & 20 & 1 & 1 \\
Okul 2 & 1996 & 1500 & 400 & 200 & 5 & 1 \\
Okul 3 & 1995 & 600 & 110 & 40 & 2 K ve 1YP* & 1 \\
Okul 4 & - & 402 & 80 & 11 & 2 & 1 \\
Okul 5 & 1871 & 3000 & 450 & 50 & 5 & 2 \\
Okul 6 & 1931 & 5954 & 539 & 173 & 6 & 5 \\
Okul 7 & 1943 & 839 & 121 & 15 & 1 & 1 \\
Okul 8 & 1989 & 1675 & 300 & 150 & 3 & 2 \\
Okul 9 & 1863 & 928 & 120 & 50 & 3 & 1 \\
Okul 10 & 1985 & 810 & 70 & 12 & 1 & 1 \\
Okul 11 & 1986 & 144 & 10 & 5 & 1 & 1 \\
Okul 12 & 1996 & 1416 & 230 & 113 & $5 K$ ve 2 YP* & 1 \\
Okul 13 & 1999 & 406 & 60 & 20 & 1 & 1 \\
Okul 14 & 1999 & 437 & 101 & 6 & 1 & 1 \\
Okul 15 & 1987 & 1000 & 100 & 20 & 2 & 1 \\
\hline
\end{tabular}

* K: Kütüphaneci; YP: Yardımaı Personel

Yukarıda belirlenen veriler sonucunda yapılan yorumlar, araştırmaya katılan okullar için genellenebilmektedir. Fakat Okul 2, Okul 9 ve Okul 12'de çalışan kütüphaneci sayısı ile araştırmaya katılan kütüphaneci sayısı orantısız olduğu için yapılan değerlendirmeler bu okullar için genellenememektedir. Bu okullardan araştırmaya yalnızca birer kütüphaneci katılmış ve değerlendirmeler bir kütüphaneci görüşüne göre yapılmıştır.

\section{Okulların Okul Kültürü Boyutlarına Göre Değerlendirilmesi}

Okul kültürünün belirlenmesi için, okul kültürü altı boyuta ayrılmıştır. Her bir boyut için elde edilen veriler irdelenmiş ve bunun sonucunda yorumlar yapılmıştır. Her bir boyut için elde edilen bulgular okulun genel kültürü ile birlikte verilmiştir.

Araştırma kapsamındaki ilk kültürel boyut "örgütsel bağlılık" tır. Bu boyutta Okul 1, 2, 4, 7, 10 ve 14 üst düzeyde güçlü kültürel özelliklere sahiptir. Okul 3, 5, 8, 9, 11, 12 ve 13 örgütsel bağlılık boyutunda güçlü fakat geliştirilmesi gereken kültürel özelliklere, Okul 6 örgütsel bağlılık boyutunda vasat, Okul 15 ise zayıf kültürel özelliklere sahiptir. Örgütsel bağlılık boyutunda bütün okulların ortalamasına bakıldığında "güçlü fakat geliştirilmesi gereken" kültür özelliklerine sahip olunduğu görülmektedir. Üst düzeyde 
güçlü okul kültürünün oluşturulmasında en önemli boyut örgütsel bağlılıktır. Örgütsel bağlılık boyutu geliştirilmeden okulların başarısının ve veriminin artması beklenemez. Okulların örgütsel bağlılık boyutu ile ilgili verileri Tablo VI’da sunulmuştur.

Tablo VI. Örgütsel Bağlılık

\begin{tabular}{lcc}
\hline & Örgütsel Bağlılık & Okul Kültürü \\
\hline Okul 1 & $\bar{X}$ & $\boldsymbol{\Sigma} \bar{X}$ \\
Okul 2 & 5,00 & 4,34 \\
Okul 3 & 4,33 & 4,31 \\
Okul 4 & 3,67 & 3,69 \\
Okul 5 & 4,33 & 4,00 \\
Okul 6 & 3,67 & 3,78 \\
Okul 7 & 3,33 & 3,47 \\
Okul 8 & 4,33 & 4,03 \\
Okul 9 & 4,17 & 3,89 \\
Okul 10 & 4,00 & 3,74 \\
Okul 11 & 5,00 & 4,57 \\
Okul 12 & 3,67 & 3,60 \\
Okul 13 & 3,67 & 3,26 \\
Okul 14 & 4,00 & 2,71 \\
Okul 15 & 5,00 & 4,91 \\
Kültürel Boyut $\Sigma \bar{X}$ & 2,00 & 2,03 \\
\hline
\end{tabular}

Okul kültürü boyutlarından bir diğeri etkili iletişimdir. Etkili iletişim boyutunda Okul 1, $2,7,8,10,12$ ve 14 üst düzeyde güçlü kültür özelliklerine sahiptir. Okul 3, 4, 5, 6, 7, 9 ve 11 güçlü fakat geliştirilmesi gereken kültür özellikleri sergilemektedir. Bu boyutta Okul 13 vasat kültür özelliği sergilerken, Okul 15 ise zayıf kültür özelliği göstermektedir.

Okulüyeleriarasında sürekli ve etkili bir bilgi akışının olması, sorun veya önerilerin ilgili yerlere bildirilmesi, okul ile öğrenci ve çevre arasında iyi ilişkiler olması, okul kültürünün geliştirilmesinde önemlidir. Etkili iletişim boyutunda okulların genel ortalaması "güçlü fakat geliştirilmesi gereken" kültür özelliklerine sahiptir. Bu veriler doğrultusunda okul kütüphanelerinde çalışan kütüphanecilerin birbirleriyle, yöneticilerle ve öğretmenlerle iyi ilişkiler kurduğu söylenebilir. Etkili iletişim ile ilgili bulgular Tablo VII'de yer almaktadır. 
Tablo VII. Etkili İletişim

\begin{tabular}{lcc}
\hline & Etkili iletişim & Okul Kültürü \\
\hline Okul 1 & $\bar{X}$ & $\boldsymbol{\Sigma} \bar{X}$ \\
Okul 2 & 4,67 & 4,34 \\
Okul 3 & 4,67 & 4,31 \\
Okul 4 & 3,67 & 3,69 \\
Okul 5 & 3,67 & 4,00 \\
Okul 6 & 3,83 & 3,78 \\
Okul 7 & 3,80 & 3,47 \\
Okul 8 & 4,50 & 4,03 \\
Okul 9 & 4,33 & 3,89 \\
Okul 10 & 4,00 & 3,74 \\
Okul 11 & 5,00 & 4,57 \\
Okul 12 & 4,00 & 3,60 \\
Okul 13 & 4,67 & 3,26 \\
Okul 14 & 3,00 & 2,71 \\
Okul 15 & 5,00 & 4,91 \\
Kültürel Boyut $\Sigma \bar{X}$ & 1,67 & 2,03 \\
\hline
\end{tabular}

Okullarda işbirliği ve güven, gelişmiş bir okul kültürünün belirgin özelliklerindendir. İşbirliği boyutunda, Okul 1, 4, 9, 10 ve 14 üst düzeyde güçlü kültür özelliklerine sahiptir. Okul 2, 3, 5, 6, 7, 8, 11, 12 ve 15 işbirliği boyutunda güçlü fakat geliştirilmesi gereken kültürel özellikleri sergilemektedir. Okul 13 bu boyutta vasat kültürel özellikler göstermektedir. Hiçbir okulda işbirliği ve güven boyutunda zayıf özelliğe rastlanmamıştır. Okulların çoğunda kütüphaneciler ile öğretmenler arasında işbirliği olduğu, fakat geliştirilmesi gerektiği söylenebilir. Iş̧birliği olan okullarda güven ortamı da oluşturulmuş demektir.

İşbirliği boyutunda okulların genel ortalamasına bakıldığında "güçlü fakat geliştirilmesi gereken" kültür özelliği sergiledikleri görülmektedir. Kütüphanecilerin yöneticilerine karşı güven boyutunda ortalamaları "güçlü fakat geliştirilmesi gereken" özelliktedir. Kişi bazında bakıldığında araştırmaya katılan kütüphanecilerin çoğu $(\% 42,8)$ yöneticilerine duydukları güven konusunda zayıf görüş belirtmişlerdir. İşbirliği ve güven boyutu ile ilgili verilere Tablo VIII'den ulaşılabilir. 
Tablo VIII. İşbirliği ve Güven

\begin{tabular}{lcc}
\hline & İşbirliği ve Güven & Okul Kültürü \\
\hline Okul 1 & $\bar{X}$ & $\boldsymbol{\Sigma} \bar{X}$ \\
Okul 2 & 4,20 & 4,34 \\
Okul 3 & 3,80 & 4,31 \\
Okul 4 & 3,80 & 3,69 \\
Okul 5 & 4,30 & 4,00 \\
Okul 6 & 3,85 & 3,78 \\
Okul 7 & 3,96 & 3,47 \\
Okul 8 & 3,80 & 4,03 \\
Okul 9 & 3,95 & 3,89 \\
Okul 10 & 4,60 & 3,74 \\
Okul 11 & 4,80 & 4,57 \\
Okul 12 & 3,90 & 3,60 \\
Okul 13 & 3,50 & 3,26 \\
Okul 14 & 2,70 & 2,71 \\
Okul 15 & 4,90 & 4,91 \\
Kültürel Boyut $\Sigma \bar{X}$ & 3,40 & 2,03 \\
\hline
\end{tabular}

Destek boyutunda sadece Okul 1, 10 ve 14 üst düzeyde güçlü kültürel özellikler sergilemektedir. Destek boyutunda Okul 2, 3, 4, 5, 6, 7, 8 ve 9 güçlü fakat geliştirilmesi gereken kültür özelliklerine sahiptir. Bu boyutta Okul 11 ve 13 vasat, Okul 12 ve 15 zayıf kültür özellikleri sergilemektedir. Okulların bu boyuttaki genel ortalamalarına bakıldığında "güçlü fakat geliştirilmesi gereken" özellikte oldukları görülmektedir. Kütüphanecilerin bir kısmı $(\% 28,5)$ okullarında öğretimsel yenileşmelerin desteklenmesi ve öğrenmenin öğrenciler için zevkli hale getirilmesi konularında "üst düzeyde güçlü" özellikler gösteren uygulamaların yapıldığını ve yönetim tarafından desteklendiklerini ifade etmişlerdir. Yine bir kısmı (\%38), bu uygulamaların "güçlü fakat geliştirilmesi gereken" ölçüde olduğunu ifade etmiş̧tir. Kütüphanecilerin \%19’u ise bu konuda vasat ve zayıf özelliklerde uygulamalar yapıldığını belirtmişlerdir.

Okulların \%20'si kütüphanelerini bütçe ve teknoloji açılarından üst düzeyde desteklemektedir. Okulların \%46,6'sı desteklemekte, fakat bu desteklerini daha da geliştirmeleri gerekmektedir. Okulların \%33,4'i ise bu konularda çok destek görmemektedir. İlgili veriler Tablo IX'da yer almaktadır. 
Tablo IX. Destek

\begin{tabular}{lcc}
\hline & Destek & Okul Kültürü \\
\hline Okul 1 & $\overline{\mathbf{X}}$ & $\boldsymbol{\Sigma} \overline{\mathbf{X}}$ \\
Okul 2 & 4,83 & 4,34 \\
Okul 3 & 4,17 & 4,31 \\
Okul 4 & 3,83 & 3,69 \\
Okul 5 & 3,50 & 4,00 \\
Okul 6 & 3,83 & 3,78 \\
Okul 7 & 3,48 & 3,47 \\
Okul 8 & 4,17 & 4,03 \\
Okul 9 & 4,00 & 3,89 \\
Okul 10 & 3,80 & 3,74 \\
Okul 11 & 4,33 & 4,57 \\
Okul 12 & 3,33 & 3,60 \\
Okul 13 & 2,50 & 3,26 \\
Okul 14 & 2,67 & 2,71 \\
Okul 15 & 5,00 & 4,91 \\
Kültürel Boyut $\Sigma \bar{X}$ & $\mathbf{3 , 6 7}$ & 2,03 \\
\hline
\end{tabular}

Güçlü okul kültürü boyutlarından bir diğeri "motivasyon ve verimlilik" tir. Bulgulara göre okullarda görev yapan kütüphanecilerin motivasyonu, Okul 1, 2 ve 14 için üst düzeyde güçlü, Okul 3, 4, 5, 7, 8, 10 ve 11 için güçlü fakat geliştirilmesi gereken, Okul 12 ve 6 için vasat, Okul 9, 13 ve 15 için zayıftır. İşbirliği, güven, etkili iletişim ve olumlu insan ilişkilerinin olduğu okul kültüründe motivasyon ve verimliliğin de artması beklenir. Okulların motivasyon boyutundaki ortalamalarına bakıldığında"güçlü fakat geliştirilmesi gereken" özellikte oldukları söylenebilir. Araştırmaya katılan kütüphanecilerin bir kısmı $(\% 23,8)$, çalıştıkları kurumları ideal yerler olması ve görevlerini huzur içinde yapmaları açısından üst düzeyde güçlü yerler olarak belirtmişlerdir. Bu değerlendirmenin ardından, kütüphanelerin \%38,1'inin güçlü fakat geliştirilmesi gereken ölçüde, \%38,1'inin de vasat ve zayıf ölçüde olduğu gerçeği ortaya çıkmıştır. Motivasyon konusunda olumsuz görüşlerin fazlalığı dikkat çekicidir. Yine kütüphanecilerin motivasyonu artırmada etkili olan mesleki anlamda gelişimlerinin desteklenmesi ve kurumda yükselme olanaklarının bulunması konusunda, araştırmaya katılan kütüphanecilerin hiçbirisi olumlu görüş bildirmemiştir. Bu da okul kütüphanecilerinin yükselme ve mesleki gelişim konusunda yeterli destek görmediklerini ortaya çıkarmaktadır. İlgili veriler Tablo X'de verilmiştir. 
Tablo X. Motivasyon ve Verimlilik

\begin{tabular}{lcc}
\hline & $\begin{array}{c}\text { Kütüphanecilerin } \\
\text { Motivasyonu }\end{array}$ & Okul Kültürü \\
\hline Okul 1 & $\overline{\mathbf{X}}$ & $\boldsymbol{\Sigma} \overline{\mathbf{X}}$ \\
Okul 2 & 4,67 & 4,34 \\
Okul 3 & 4,67 & 4,26 \\
Okul 4 & 3,67 & 3,69 \\
Okul 5 & 4,00 & 4,00 \\
Okul 6 & 3,42 & 3,73 \\
Okul 7 & 3,61 & 3,75 \\
Okul 8 & 4,00 & 4,03 \\
Okul 9 & 2,17 & 3,74 \\
Okul 10 & 4,00 & 4,57 \\
Okul 11 17 & 3,60 \\
Okul 12 & 3,50 & 3,26 \\
Okul 13 & 2,83 & 2,71 \\
Okul 14 & 1,83 & 4,91 \\
Okul 15 & 5,00 & 3,89 \\
Kültürel Boyut $\Sigma \bar{X}$ & 3,75 & 2,03 \\
\hline
\end{tabular}

Demokratik yönetim ve katılım boyutu için Okul 2, 10 ve 14 üst düzeyde güçlü; Okul 1, 4, 5, 7, 8 ve 9 güçlü fakat geliştirilmesi gereken; Okul 3, 6, 11, 12 ve 13 vasat; Okul 15 zayıf kültürel özellikler sergilemektedir. Okullarda genel ortalamaya bakıldığında, demokratik yönetim ve katılım boyutunda da güçlü fakat geliştirilmesi gereken özellik görülmektedir. Kütüphanecilerin görüş ve düşüncelerini açıkça ifade etmeleri, görevlerini özgür bir ortamda yapmaları ve görevleriyle ilgili belirsizliklerde kendi başlarına karar verebilmeleri demokratik yönetim açısından çok önemlidir. Araştırmaya katılan kütüphanecilerin çok az bir kısmı $(\% 9,5)$ bunu yapabildiklerini ifade etmiştir. Kütüphanecilerin bir kısmı $(\% 33,3)$ kısmen yapabildiklerini, çoğunluğu ise $(57,2)$ yapamadıklarını belirtmişlerdir. Okullarda eşit davranma ve ödül dağıtımındaki adalet konularında ise kütüphanecilerin bir kısmı (\%19) üst düzey özellikte; \%33,3'ü geliştirilmesi gereken özellikte, \%47,7'sı ise vasat ve zayıf özellikteki kütüphane uygulamalarından bizleri haberdar etmişlerdir. Kütüphane ile ilgili karar verme komitelerinde yer alma ve kütüphanecilerin kişiliklerine saygı gösterilmesi konularında \%43'ü üst düzey özellik gösteren davranışlar olduğunu, \%28,5'i geliştirilmesi gereken, $\% 28,5^{\prime} \mathrm{i}$ de vasat ve zayıf özellikte olduğunu ifade etmişlerdir. Demokratik yönetim ve katılım ile ilgili ortalamalar Tablo XI'de yer almaktadır. 
Tablo XI. Demokratik Yönetim ve Katılım

\begin{tabular}{lcc}
\hline & Demokratik Yönetim ve Katılım & Okul Kültürü \\
\hline & $\overline{\mathbf{X}}$ & $\boldsymbol{\Sigma} \overline{\mathbf{X}}$ \\
Okul 1 & 3,63 & 4,34 \\
Okul 2 & 4,75 & 4,31 \\
Okul 3 & 3,38 & 3,69 \\
Okul 4 & 4,00 & 4,00 \\
Okul 5 & 3,72 & 3,78 \\
Okul 6 & 2,95 & 3,47 \\
Okul 7 & 4,00 & 4,03 \\
Okul 8 & 3,56 & 3,89 \\
Okul 9 & 3,63 & 3,74 \\
Okul 10 & 4,53 & 4,57 \\
Okul 11 & 3,25 & 3,60 \\
Okul 12 & 3,25 & 3,26 \\
Okul 13 & 2,88 & 2,71 \\
Okul 14 & 4,75 & 4,91 \\
Okul 15 & 1,38 & 2,03 \\
Kültürel Boyut $\Sigma \overline{\mathbf{X}}$ & $\mathbf{3 , 5 8}$ & $\mathbf{3 , 7 6}$ \\
\hline
\end{tabular}

Son olarak okulların bütün boyutlarda sergiledikleri kültür özellikleri Tablo XII'de toplu olarak verilmiştir.

Tablo XII. Okulların Bütün Boyutlara Göre Kültür Özellikleri*

\begin{tabular}{|c|c|c|c|c|c|c|c|}
\hline \multicolumn{8}{|c|}{ Kültür Boyutları } \\
\hline Okul & $\begin{array}{l}\text { Örgütsel } \\
\text { Bağlılık }\end{array}$ & $\begin{array}{c}\text { Etkili } \\
\text { Iletişim }\end{array}$ & $\begin{array}{l}\text { İşbirliği } \\
\text { ve Güven }\end{array}$ & Destek & $\begin{array}{l}\text { Motivasyon } \\
\text { ve Verimlilik }\end{array}$ & $\begin{array}{c}\text { Demokratik } \\
\text { Yönetim ve } \\
\text { Katılım }\end{array}$ & $\begin{array}{c}\text { Genel } \\
\text { Okul } \\
\text { Kültürü }\end{array}$ \\
\hline Okul 1 & $\ddot{U}$ & $\ddot{U}$ & $\ddot{U}$ & $\ddot{U}$ & $\ddot{U}$ & $G$ & Ü \\
\hline Okul 2 & Ü & Ü & G & G & Ü & Ü & Ü \\
\hline Okul 3 & G & G & G & G & G & V & G \\
\hline Okul 4 & Ü & G & Ü & G & G & G & G \\
\hline Okul 5 & G & G & G & G & G & G & G \\
\hline Okul 6 & V & G & G & G & V & V & G \\
\hline Okul 7 & Ü & Ü & G & G & G & G & G \\
\hline Okul 8 & G & Ü & G & G & G & G & G \\
\hline Okul 9 & G & G & Ü & G & Z & G & G \\
\hline Okul 10 & Ü & Ü & Ü & Ü & G & Ü & Ü \\
\hline Okul 11 & G & G & G & V & G & V & G \\
\hline Okul 12 & G & Ü & G & Z & V & V & V \\
\hline Okul 13 & G & V & V & V & Z & V & V \\
\hline Okul 14 & $\ddot{U}$ & Ü & Ü & Ü & Ü & Ü & Ü \\
\hline Okul 15 & Z & Z & G & Z & Z & Z & Z \\
\hline
\end{tabular}

* Kullanılan kısaltmalar şunlardır:

Üst düzeyde güçlü

:Ü,

Güçlü fakat geliştirilmesi gereken

$: \mathbf{G}$

Vasat

:V,

Zayıf 


\section{Sonuç ve Öneriler}

Araştırmadan elde edilen bulgular, yöntemde de açıklandığı gibi, önce her bir kütüphanecinin görüşüne göre, sonra aynı kurumda çalışan kütüphanecilerin görüşlerinin ortalamalarına göre değerlendirilmiştir. Örneğin Okul 6'dan araştırmaya 5 kütüphaneci katılmıştır. Sadece kütüphanecilere göre değerlendirildiğinde kültür boyutları kimisine göre üst düzeyde, kimisine göre de vasat ve zayıfözellikler sergilemiştir. Çalışan kütüphanecilerin ortalaması alınarak okul kültürü ve boyutları belirlenmiştir. Araştırmaya o kurumdan tek kütüphaneci katılsaydı, okul kültürü ve boyutları ya üst düzey ya da zayıf olarak çıkabilirdi. Çalışmamızda anket tekniği kullanılmıştır ve okul içinde gözlem yapmak, bir süre bulunmak ya da okuldaki öğrenci, öğretmen, yönetici görüşlerine başvurmak gibi olanaklar sağlanamamıştır. Bu yüzden kütüphanecilerden elde edilen veriler ışığında değerlendirmeler yapılmıştır. Her kütüphanecinin okul içinde yaşadıkları olumlu ya da olumsuz durumlar ile bireysel özellikleri gibi etmenler de okul kültürü algılarını etkileyebilmektedir. Bazı kütüphanecilerin yaşadıkları olumsuzluklara rağmen, çalıştıkları kurumların olumsuzluklarını ifade etmeme gibi durumları olabileceği de göz ardı edilmemelidir. Okul 2, 9 ve 12'de olduğu gibi, sonuçlar okula genellenmemekte, sadece araştırmaya katılan kütüphanecilerin görüşlerine göre değerlendirilmektedir.

Araştırma amacına bağlı olarak yapılan çalışmalarla hipotezimiz kanıtlanmıştır. Sonuç olarak kütüphaneci görüşlerine göre, okulların sergiledikleri kültür özelliklerinin değerlendirilmesi Tablo XIII'de verilmiştir.

Tablo XIII. Araştırmaya Katılan Okulların Genel Okul Kültürü Özellikleri

\begin{tabular}{lc}
\hline Kültür Özellikleri & Okullar \\
\hline Üst düzeyde güçlü & $1, \mathbf{2}^{*}, 10,14$ \\
Güçlü fakat geliştirilmesi gereken & $3,4,5,6,7,8, \mathbf{9}^{*}, 11$ \\
Vasat & $\mathbf{1 2 *}, 13$ \\
Zayıf & 15 \\
\hline
\end{tabular}

* Bulgulardan yola çıkarak yapılan yorumlar, araştırmaya katılan okullar için genellenebilmektedir. Fakat Okul 2, Okul 9 ve Okul 12'de araştırmaya birer kütüphaneci katılmış ve değerlendirmeler bir kütüphaneci görüşüne göre yapılmıştır.

Okul Kütüphanecileri Derneğine üye olan ve Türkiye'deki 15 farklı özel okul kütüphanesinde görev yapan 21 kütüphaneciye uygulanan anket ile elde edilen veriler temelinde ulaşılan ve kütüphanecilerin görüşlerine dayalı sonuçları şöyle sıralayabiliriz:

$\diamond$ Araştırma kapsamına giren okullar genel olarak güçlü ancak geliştirilmesi gereken kültür özelliklerine sahiptir. Çok uzun süredir eğitim hayatında yer alan köklü okullar bu grup içinde yer almaktadır. Bu da okulun kuruluş tarihi ile güçlü kültür özelliği arasında doğru orantılı bir ilişki olmadığını göstermektedir. 
$\diamond$ Araştırmamızda örgütsel bağlılık boyutuna ilişkin güçlü özellikler bir bütün olarak okullarda işlerin yapılırken ortak değerlerin paylaşılmasında görülmektedir. Okul müdürünün liderliği, paylaşılan duygular, sürdürülen adetler ve gelenekler örgütsel bağlılığı artırmaktadır. İşbirliği ve yenilikçi girişimler desteklendiğinde başarı ve mutlulukla çalışmaların sürdürüleceğine inanılmaktadır.

$\diamond$ Okul 14 okul kültürünün bütün boyutlarında üst düzeyde kültürel özelliklere sahiptir. Yine Okul 1 ve Okul 10'da genel olarak üst düzey kültürel özellikler sergilemektedir. Bu da öğrenci sayısı az olan küçük okulların daha etkin olduğuna ve üst düzey kültürel özelliklere sahip olduklarına işaret etmektedir. Küçük okullarda kurum içi iletişimin sağlanması, işbirliği yapılması ve iyi ilişkilerin daha kolay kurulması mümkün olabilir.

$\checkmark$ Araştırmaya katılan okulların 6'sında bir kütüphaneci çalışmaktadır. Bunlardan Okul 1, 10 ve 14 üst düzeyde güçlü özelliklere sahipken, Okul 7 güçlü ancak geliştirilmesi gereken, Okul 11 ve 13'de vasat ve zayıf özelliklere sahiptir. Okul kütüphanelerinde tek başına çalışan kütüphaneciler, kütüphanenin bütün sorumluluğunu üstlenmek durumundadır. Böylece, yönetim ile kütüphaneci arasında etkili iletişim kurulacağı düşünülse de, başka bir kütüphaneci ile kütüphaneyi paylaşmamak ters etkilere de neden olabilmektedir. Yani tek başına bütün sorumluluğu taşımanın yükü, tek başına çalışandan çok fazla bir şey beklenmemesi ve yeterince desteklenmemesi sonucunda kütüphanecide duygusal anlamda kötümserlik gelişebilmektedir. Bunlar okul kültürü boyutlarının zayıf algılanmasında etkili olan durumlardır..

$\diamond$ Kütüphaneci görüşlerine göre, okulların en zayıf olduğu kültür boyutu "Motivasyon" dur. Araştırma kapsamında olan okullarda çalışan kütüphanecilerin \%38'i görevlerini huzur içinde yapma ve ideal bir çalışma ortamı olma konusunda vasat niteliktedirler. Ayrıca \%57'si mesleki anlamda desteklenme ve yükselme olanakları konusunda vasat ve zayıf görüş bildirmişlerdir. Kütüphanecilerin motivasyonunun yükseltilmesinde, bu durumların iyileştirilmesinin gereği açıkça görülmektedir.

$\diamond$ Okulların ikinci zayıf olduğu kültür boyutu ise "Demokratik yönetim ve katılım" boyutudur. Araştırma kapsamında olan okullarda çalışan kütüphanecilerin yine \%38'i özgür bir ortam, düşünce ve fikirlerin açıkça ifade edilmesi konusunda vasat ve zayıf görüş bildirmişlerdir. Yine görevleriyle ilgili belirsizlik durumlarında karar verme yetkisi ve fikir farklılıkları konusunda çoğu kütüphaneci $(\% 66,6)$ olumsuz görüş bildirmişlerdir. Okul içinde herkese eşit davranılması konusunda kütüphanecilerin \%61'inin olumsuz görüş bildirmesi dikkat çekicidir. Demokratik yönetimin olmadığı okul kültürlerinde, personelin verimli, huzur içinde ve yüksek motivasyonla çalışması çok zordur. Demokratik yönetim ve karar alma konularında , okul yöneticilerinin daha fazla çaba harcamasının gerekliliği ortadadır.

$\diamond$ Kütüphaneci görüşlerine göre, okulların en güçlü olduğu kültür boyutu "Etkili iletişim"dir. Kütüphanecilerin çoğu, okul müdürlerinin kapısının herkese açık olduğunu ifade etmiştir. Anlaşılacağı üzere okul müdürleri personelin şikayet ve önerilerini dinlemektedir. Burada önemli olan yöneticinin sorunlara adil ve 
yerinde çözümler üretmesidir. Bu konuda elimizde bir veri bulunmadığı için yönetici boyutu ile ilgili değerlendirme yapılamamaktadır. Yine kütüphanecilerin çoğu öğretmenlerle ve beraber çalıştıkları kütüphaneci arkadaşları ile iyi iletişim kurduklarını ifade etmişlerdir.

$\checkmark$ Birçok soruda olumsuz görüş bildiren kütüphanecilerin, örgütsel bağlılık boyutunda güçlü özellikler sergilemeleri dikkat çekicidir.

$\diamond \quad$ Işbirliği ve güven boyutunda güçlü fakat geliştirilmesi gereken kültür özelliklerine rastlanmıştır. İşbirliği boyutunda kütüphanecilerin bilgisinin ve çabasının etkili olduğu söylenebilir. Sorulara verilen cevaplar incelendiğinde kütüphanecilerin yöneticilerine karşı duydukları güvende vasat özelliklerin çokluğu önemlidir.

$\diamond$ Destek boyutunda okulların çoğu geliştirilmesi gereken özellikler sergilemektedir. Özellikle kütüphanelerin teknolojik açıdan desteklenmesi ve iyi bir bütçenin sağlanması konusunda destek verilmesi gerekmektedir.

Elde edilen ve yukarıda sıralanan sonuçlara dayanarak şu öneriler sunulabilir:

$\checkmark \quad$ Okul yöneticilerinin kütüphane ve kütüphaneci kavramları konusunda yeterince bilgi sahibi olmamaları dolayısıyla, kütüphanelerin okul kültürü içinde nerede yer aldıklarının belli olmaması kütüphaneciye karşı bakış açısının olumlu olmasını engellemektedir. Okul kütüphanelerinin bir birim olarak doğrudan yönetime bağlı olarak çalışması, kütüphane ile ilgili kararlarda kütüphanecilerin yer alması, kütüphanecilerin diğer birim ve kişilerle işlevsel ve anlamlı işbirliğine ve etkileşime girebilmesi gerekmektedir.

$\diamond$ Güçlü okul kültürünün yapılandırılmasında lider konumda olan yöneticiler, kurumlarında çalışan kütüphanecilerin motivasyonlarınn artırılması konusunda daha fazla çaba göstermeli ve daha demokratik ortamlar sağlamalıdır.

$\checkmark$ Günlük yaşantıların büyük bir bölümünün işte geçirilmesi, insanların mutlu olabilmeleri için yalnızca ekonomik durumun değil, psikolojik durumun da önemli olduğu gösterilmiştir. Bu durumda iş tatminiyle ilgili uygulamalarda, örgüt kültürü konusuna önem verilmesi zorunlu hale gelmelidir.

$\checkmark$ Kütüphaneler, kendilerini tanımak adına özelliklerini belirlemeli, bulundukları örgütte mevcut kültür düzeyini göz önüne sererek bunların güçlü ve zayıf yönlerini tespit etmeli, nasıl daha fazla fayda sağlayacaklarını düşünmelidirler.

$\checkmark \quad$ Okul kültüründe kütüphanenin nasıl yer alması ve sürdürülmesi gerektiğini öğreten hizmet içi eğitim kursları düzenlenerek okul personeli yani yöneticiler, öğretmenler ve kütüphaneciler bu konuda yeterlilik kazanmalıdır.

$\diamond \quad$ Okul yöneticileri kütüphaneci - öğretmen işbirliğini desteklemeli ve öğretmenleri bu konuda yönlendirmelidir. İşbirliğinin sürekliliğini sağlamalıdır.

$\diamond \quad$ Okul kütüphanecileri de işbirliği konusunda özel çaba harcamalı ve kütüphane ile yapılacak işbirliğinin önemi konusunda yönetimi ve öğretmenleri bilinçlendirmeye ve yönlendirmeye çalışmalıdır. 
$\diamond$ Okul yöneticileri tarafından, teknolojik gelişmelere uyum sağlama ve kaynak çeşitliliğini artırma konusunda kütüphanelere destek verilmesi ve kütüphanecilerin mesleki ve kişisel gelişimlerinin desteklenmesi sağlanmalıdır.

$\diamond \quad$ Okullar arasında bilgi ve deneyimleri paylaşım toplantıları düzenlenmelidir.

$\diamond$ Bu araştırmanın örneklemi genişletilerek tekrarlanmalıdır.

$\diamond$ Araştırmayı tamamlaması açısından, bu konuyla ilgili öğretmen, yönetici, öğrenci ve veli görüşleri de alınarak okul kütüphanelerinin okul kültürü içinde değerlendirildiği başka araştırmaların yapılması uygun olabilir.

Güçlü okul kültürünün varlığı, kütüphanelerin etkinliğinin artırılması ve okul başarısının yükseltilmesinde önemli bir etkendir. Güçlü okul kültürü oluşturulmasında lider konumda olan okul yöneticilerinin bunu fark etmesi ve sahip oldukları okul kültürünü her boyutuyla geliştirmeleri büyük önem taşımaktadır. Elde edilecek başarının sadece eğitimde kütüphane hizmetlerinin varlığını görmeye değil, eğitimin amaçlarının gerçekleştirilmesine yönelik olduğu unutulmamalıdır.

\section{Kaynakça}

Alganer, C.U. (2000). Örgütlerin kuruluş dönemlerinde örgüt kültürü oluşturmaları sırasında karşılaştıkları sorunlar. Yayımlanmamış Yüksek Lisans Tezi. Ankara: Ankara Üniversitesi Sosyal Bilimler Enstitüsü.

Atay, K. (2001). Öğretmen yönetici ve denetmenlerin bakış açısından okul kültürü ve öğretmen verimliliğine etkisi. Kuram ve Uygulamada Eğitim Yönetimi, 25, 179-194.

Balcı, A. (1993). Etkili okul: Kuram, uygulama ve araştırma. Ankara: Erek Ofset.

Berg, M.F. (2005). Shaping school culture while implementing a structured in school Improvement plan. Yayımlanmamış doktora tezi. University of Wisconsin, Madison.

Brown, K.L.Z. (2005). An examination of the relationship between school culture and student achievement on Ohio sixth-grade proficiency tests. Yayımlanmamış doktora tezi, Kent State University, Ohio.

Celep, C. (2002). İlköğretim okullarında öğrenme kültürü. Kuram ve Uygulamada Eğitim Yönetimi, 31, 356-373.

Demirtaş, Z. (2010). Okul kültürü ile öğrenci başarısı arasındaki ilişki. Eğitim ve Bilim, 35(158), 3-13.

Dinçer, Ö. (1992). Stratejik yönetim ve işletme politikası, İstanbul: Beta Yayınları.

Erdem, F. ve Özen-İşbaşı, J. (2001). Eğitim kurumlarında örgüt kültürü ve öğrenci alt kültürünün algılamaları. Akdeniz I.I.B.F. Dergisi, 1, 33-57.

Fırat, N. (2007). Okul kültürü ve öğretmenlerin değer sistemleri. Yayımlanmamış doktora Tezi. Dokuz Eylül Üniversitesi, İzmir.

Güçlü, N. (2003). Örgüt kültürü. Kırgızistan Manas Üniversitesi, Sosyal Bilimler Dergisi, 6, 147-159.

Howard, J.K. (2008). The relationship between school culture and an effective school library program: four case studies. Yayımlanmamış yüksek lisans tezi, Emporia State University, Emporia. 
Önal, H.I. (Çev.). (1999). IFLA / UNESCO Okul Kütüphanesi Bildirgesi.12 Aralık 2011 tarihinde http:// www.kutuphaneci.org.tr/index.php?option=com_content $\&$ view=article\&id=146\&ltem $\mathrm{id}=119$ adresinden erişildi.

Önal, H.I. (2005). New developments on the Turkish school library scene. Journal of Librarianship and Information Science, 37(3), 141-152.

Özdemir, A. (2006). Okul kültürünün oluşturulması ve çevreye tanıtılmasında okul müdürlerinden beklenen ve onlarda gözlenen davranışlar. Türk Eğitim Bilimleri Dergisi, 4(4), 411-433.

Pehlivanoğlu, K. (1999). Özel ortaöğretim kurumlarındaki yönetici ve öğretmenlerin örgüt kültürü oluşturmadaki yeterlilik derecesi. Yayımlanmamış yüksek lisans tezi. Yıldız Teknik Üniversitesi, İstanbul.

Scholastic Library Publishing (2008). Okul kütüphaneleri etkili oluyor. (Yaratıcı Kütüphane Girişimleri Grubu, Çev.). 25 Aralık 2011 tarihinde http://www.ilipg.org/sites/ilipg.org/files/ documents/2011/02/school-libraries-work-scholastic-library-publishingtr.pdf adresinden erişildi.

Şahin, S. (2010). Okul Kültürünün bazı değişkenler açısından incelenmesi. Illköğretim Online, 9(2), 561-575. 25 Aralık 2011 tarihinde http://ilkogretim-online.org.tr adresinden erişildi.

Şimşek, Y. (2003). Okul müdürlerinin iletişim becerileri ile okul kültürü arasındaki ilişki (Eskişehir ili örneği). Yayımlanmamış doktora tezi. Anadolu Üniversitesi, Eskişehir.

EK 1.

\begin{tabular}{ll}
\multicolumn{2}{c}{ Araştırma Kapsamında Yer Alan Okullar* } \\
\hline Okulun Adı & Bulunduğu İ \\
\hline Açı Koleji & İstanbul \\
Aka Koleji & İstanbul \\
Darüşşafaka Eğitim Kurumları & İstanbul \\
Hisar Okulları & İstanbul \\
İstek Vakfı Okulu & İstanbul \\
İstek Vakfı Semiha Şakir Lisesi & İstanbul \\
MEF Okulları & İstanbul \\
ODTÜ Geliştirme Vakfı Ankara Koleji & Ankara \\
ODTÜ Geliştirme Vakfı Mersin Koleji & Mersin \\
Özel Bilkent İlköğretim Okulu & Ankara \\
Özel Irmak Okulları & İstanbul \\
Özel Sezin Okulu & İstanbul \\
TED Ankara Koleji & Ankara \\
TED İstanbul Koleji & İstanbul \\
Terakki Vakfı Okulları & İstanbul \\
\hline
\end{tabular}

* Okullar alfabetik sırada dizilmiştir. 
EK 2.

OKUL KÜLTÜRÜ VE KÜTÜPHANE ILIŞKISI ANKETI

Bu anket, bilimsel araştırma amacıyla hazırlanmıştır. Bu nedenle anketi doldurmanız ve sorularda size en uygun seçeneği içtenlikle yanıtlamanız büyük önem taşımaktadır.

Elde edilecek veriler kișisel değerlendirmeye tabi tutulmayacaktır. Bu nedenle lütfen isim yazmayınız.

Zaman ayırdığınız ve yardımcı olduğunuz için teşekkür ederiz.

H. İnci ÖNAL - Selda EKICi

1. Cinsiyetiniz?

( ) Erkek ( ) Kadın

2. Yaşınız?

( ) 30 yaş altı

( ) $31-40$

( ) 41 ve üzeri

3. En son mezun olduğunuz öğretim programı nedir?

( ) 2 yıllık ön lisans programı

( ) 4 yıllık lisans programı

( ) Yüksek Lisans Programı

( ) Doktora Programı

( ) Diğer

4. En son mezun olduğunuz bölümün I ana bilim dalının adını yazınız.

5. Okuldaki görev süreniz nedir?

( ) 1 yıl ve daha az

( ) 2-5 yıl

( ) 6-10 yıl

( ) 11 yıl ve üstü
6. Kadronuz nedir?

( ) Memur

( ) Kütüphaneci

( ) Şef / Birim sorumlusu

( ) Müdür

( ) Diğer

7. Bulunduğunuz kadro ile mi göreve başladınız?

( ) Evet ( ) Hayır

8. Göreve başladıktan sonra görevde yükselme yaşadınız mı?

( ) Evet ( ) Hayır

9. Okulunuzun kuruluş tarihi nedir?

10. Okulunuzda kaç öğrenci ve kaç personel bulunmaktadır?

Öğrenci sayısı

Öğretmen sayısı

Personel sayısı

Kütüphaneci sayısı 
Açıklama: Aşağıda okullardaki durum ve özellikleri anlatan ifadeler yer almaktadır. Kendi okulunuzdaki durum ve özellikleri göz önünde bulundurarak bu ifadelere ne kadar katıldığınızı göstermeniz için sağdaki kutucuklardan uygun olan birini $(X)$ ile işaretleyiniz.

\begin{tabular}{|c|c|c|c|c|c|c|}
\hline & \multirow{2}{*}{$($ ) } & \multirow{2}{*}{\begin{tabular}{|l|}
$\underline{\tilde{C}}$ \\
$(\quad)$
\end{tabular}} & \multirow{2}{*}{ 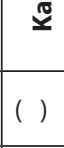 } & \multirow{2}{*}{\begin{tabular}{|l}
$\ddot{\mathbb{x}}$ \\
$(\quad)$
\end{tabular}} & \multirow{2}{*}{\begin{tabular}{|l|} 
高 \\
$($ )
\end{tabular}} \\
\hline 1 & $\begin{array}{l}\text { Okulumuz çalışanların görevlerini özgür bir ortamda } \\
\text { yaparlar. }\end{array}$ & & & & & \\
\hline 2 & $\begin{array}{l}\text { Okulumuzda herkes, düşünce ve görüşlerini açıkça ifade } \\
\text { edebilir. }\end{array}$ & $($ ) & $(）$ & $($ ) & $(）$ & $($ ) \\
\hline 3 & Okulumuzda "ben" bilincinden çok "biz" bilinci vardır. & ( ) & $(1)$ & () & $($ ) & $($ ) \\
\hline 4 & $\begin{array}{l}\text { Okulumuzda görevimi huzur içinde yapma olanağı } \\
\text { bulurum. }\end{array}$ & $($ ) & $($ ) & $($ ) & $($ ) & ( ) \\
\hline 5 & $\begin{array}{l}\text { Okulumuzun yöneticileri, velileri birer mali kaynak olarak } \\
\text { görürler. }\end{array}$ & ( ) & $(）$ & $($ ) & $($ ) & $($ ) \\
\hline 6 & Okulumuzda müdür odasının kapısı herkese açıktır. & $($ ) & $(）$ & $(）$ & () & $($ ) \\
\hline 7 & $\begin{array}{l}\text { Okulumuz çalışanları, görevleriyle ilgili bir belirsizlik söz } \\
\text { konusu olduğunda kendi başlarına karar verebilirler. }\end{array}$ & $($ ) & $($ ) & $($ ) & $($ ) & ( ) \\
\hline 8 & $\begin{array}{l}\text { Okulumuzda fikir farklılıkları birer öğrenme fırsatı olarak } \\
\text { değerlendirilir. }\end{array}$ & ( ) & $($ ) & $($ ) & $($ ) & ( ) \\
\hline 9 & $\begin{array}{l}\text { Okulumuz çalışanları, okulun parasal kaynaklarının } \\
\text { kullanımı konusunda okul yönetimine güvenirler. }\end{array}$ & ( ) & ( ) & $($ ) & $($ ) & ( ) \\
\hline 10 & $\begin{array}{l}\text { Diğer okullarla karşılaştırıldığında okulumuz, çalışılacak } \\
\text { ideal bir yerdir. }\end{array}$ & ( ) & ( ) & $(1)$ & $($ ) & ( ) \\
\hline 11 & $\begin{array}{l}\text { Okulumuz çalışanları, birbirlerinin başarısından mutluluk } \\
\text { duyarlar. }\end{array}$ & ( ) & $($ ) & $($ ) & $($ ) & ( ) \\
\hline 12 & $\begin{array}{l}\text { Okulumuzda herkese eşit davranma, temel bir değer } \\
\text { olarak benimsenir. }\end{array}$ & ( ) & ( ) & $(1)$ & $($ ) & ( ) \\
\hline 13 & $\begin{array}{l}\text { Okulumuzda kütüphanenin varlığı, öğrenci başarısına } \\
\text { yansımaktadır. }\end{array}$ & ( ) & $($ ) & $(1)$ & $(1)$ & ( ) \\
\hline 14 & $\begin{array}{l}\text { Okulumuz öğretmenleri, yöneticileri ve kütüphanecileri } \\
\text { arasında bilgi, deneyim, kaynak vb. alışverişi yok denecek } \\
\text { kadar azdır. }\end{array}$ & $($ ) & ( ) & $($ ) & $($ ) & ( ) \\
\hline 15 & Okulumuzun başarılı bir okul olması beni mutlu eder. & $($ ) & $(）$ & $(）$ & $($ ) & $($ ) \\
\hline 16 & $\begin{array}{l}\text { Okulumuzda ödül dağıtımında temel ölçüt, okul } \\
\text { yönetimine yakın olmaktır. }\end{array}$ & ( ) & $($ ) & $($ ) & $($ ) & ( ) \\
\hline 17 & $\begin{array}{l}\text { Okulumuzda öğretmenler ile kütüphaneciler arasında } \\
\text { yeterli iletişim vardır. }\end{array}$ & ( ) & $($ ) & $(）$ & ( ) & $($ ) \\
\hline
\end{tabular}




\begin{tabular}{|c|c|c|c|c|c|c|}
\hline 18 & Bu okulda öğretimsel yenileşmeler desteklenmektedir. & $($ ) & ( ) & $($ ) & $($ ) & ( ) \\
\hline 19 & $\begin{array}{l}\text { Bu okulda öğrenme, öğrenciler için zevk alınacak bir } \\
\text { etkinlik olarak düzenlenmeye çalışılmaktadır. }\end{array}$ & $($ ) & ( ) & $($ ) & ( ) & ( ) \\
\hline 20 & $\begin{array}{l}\text { Bu okulda, öğrencilere okulda öğrendiklerini okul } \\
\text { dışındaki yaşantılarında nasıl kullanacaklarını gösterme } \\
\text { konusunda gerçek bir çaba harcanmaktadır. }\end{array}$ & $($ ) & ( ) & $($ ) & $($ ) & ( ) \\
\hline 21 & $\begin{array}{l}\text { Bu okuldaki çalışma ortamı kütüphanecileri çok } \\
\text { çalışmaya istekli kılmaktadır. }\end{array}$ & ( ) & ( ) & $($ ) & ( ) & ( ) \\
\hline 22 & $\begin{array}{l}\text { Kütüphaneci olarak öğrencilere okuma alışkanlığı } \\
\text { kazandırıımasına ve kütüphane kaynaklarının } \\
\text { kullanımına yönelik etkinlikler düzenlemek için özel bir } \\
\text { çaba harcıyorum. }\end{array}$ & $($ ) & ( ) & ( ) & ( ) & ( ) \\
\hline 23 & Bilgi okuryazarlığı konusunda bilgiliyim. & $($ ) & ( ) & ( ) & ( ) & ( ) \\
\hline 24 & $\begin{array}{l}\text { Bilgi okuryazarlığı konusunda öğretmenlerle ve } \\
\text { yönetimle işbirliği yapıyorum. }\end{array}$ & $($ ) & ( ) & $($ ) & ( ) & ( ) \\
\hline 25 & Bilgisayar okuryazarlığı konusunda bilgiliyim. & $($ ) & ( ) & $($ ) & () & ( ) \\
\hline 26 & $\begin{array}{l}\text { Bilgisayar okuryazarlığı konusunda öğretmenlerle } \\
\text { işbirliği yapıyorum. }\end{array}$ & $(\mathrm{)}$ & ( ) & $($ ) & ( ) & ( ) \\
\hline 27 & $\begin{array}{l}\text { Okulumuzda kütüphanecilerin kişiliklerine saygı } \\
\text { gösterilmektedir. }\end{array}$ & $($ ) & ( ) & $($ ) & $($ ) & ( ) \\
\hline 28 & $\begin{array}{l}\text { Öğretmenler sınıftaki imkanları değiş̧irmek için } \\
\text { kütüphanecilerle işbirliği yapmakta ve öğrenimi } \\
\text { kitaplar, elektronik kaynaklar ve diğer unsurlarla } \\
\text { desteklemektedir. }\end{array}$ & $($ ) & ( ) & ( ) & ( ) & ( ) \\
\hline 29 & $\begin{array}{l}\text { Okul yönetimi mesleki anlamda gelişimimi } \\
\text { desteklemektedir. }\end{array}$ & $(\mathrm{)}$ & ( ) & $($ ) & ( ) & ( ) \\
\hline 30 & Okulumuzda yükselme olanakları vardır. & $($ ) & ( ) & ( ) & ( ) & ( ) \\
\hline 31 & $\begin{array}{l}\text { Kütüphanemiz teknolojik gelişmelere uyum } \\
\text { sağlamaktadır. }\end{array}$ & $($ ) & $($ ) & ( ) & $($ ) & ( ) \\
\hline 32 & Kütüphanemizin yeterli bir bütçesi vardır. & $($ ) & ( ) & $($ ) & ( ) & ( ) \\
\hline 33 & $\begin{array}{l}\text { Yönetim, okulumuz kütüphanesinde mutlaka } \\
\text { kütüphanecilik eğitimi almış kişilerin çalıştırılmasını } \\
\text { uygun bulur. }\end{array}$ & $($ ) & ( ) & $($ ) & ( ) & ( ) \\
\hline 34 & $\begin{array}{l}\text { Okulumuz kütüphanesi ile ilgili kararların alınmasında, } \\
\text { yönetim, kütüphanecilerin düşüncelerini ve isteklerini } \\
\text { göz önünde bulundurur. }\end{array}$ & $(\mathrm{)}$ & ( ) & $($ ) & ( ) & $($ ) \\
\hline 35. & $\begin{array}{l}\text { Okulumuzda çalışan kütüphaneciler arasında bir uyum } \\
\text { vardır. }\end{array}$ & $($ ) & ( ) & $($ ) & ( ) & ( ) \\
\hline
\end{tabular}

\section{TEŞEKKÜR EDERIM}

